\title{
PLURALITAS AGAMA DAN KEKERASAN KOLEKTIF
}

\section{(Perspektif Sosiologi Agama)}

\author{
Oleh Muh. Yunus
}

\section{Penulis adalah Dosen Muda STAIN Malang, Sekjen. Lembaga Studi dan Pengembangan Umat GNOSIS Malang, Dewan Redaksi Jurnal Lintas Agama "Toleransi", dan anggota Lembaga Kajian Agama dan Kebudayaan "Salsabila" Malang.}

Kesan indah tentang pluralitas kehiclupan beragania di Indonesia, pernah dilontarkan oleh Prof. Mohammed Arkoun ketika pada bulan Nopember 1992 berkunjung ke negeri kita. Ia berkunjung ke Indonesia untuk menghadiri seminar "International Conference of Cultural Tourism" di Yogyakarta, dan sempat memberi ceramah di Fakultas Ushuluddin IAIN Sunan Kalijaga. Dengan penuh kekaguman, ia menyebut bahwa kerukunan hidup antar umat beragama di Indonesia adalah tipikal Qur'anik (M. Amin Abdullah, 1999: 19, catatan kaki No. 6). Kesan ini menunjukkan, bahwa bangsa kita adalah bangsa yang sangat terhormat dan dikagumi oleh dunia mengapa bangsa yang tempo dulu dikenal sangat santun dan beradab kini tiba tiba berubah menjadi beringas seperti bangsa Barbarian. Bangsa Afrika Selatan saja yang dulu dikenal tidak pernah sepi dari tindak kekerasan akibat perbedaan etnis yang sangat menonjol (apartbeid), pada akhirnya dapat didamaikan dengan kehadiran Nelson Mandela sebagai tokoli Rekonsiliasi Nasional. Ironisnya kini Indonesia justru belajar bagaimana melakukan

Rekonsiliasi Nasional dari pengalaman A frika Selatan itu. internasional dalam hal kerukunan antar umat beragama.

Tetapi belakangan ini, kesan itu penuh paradok. Kesan negatif itu tampak seperti apa yang diungkapkan oleh Dr. H. Agiel Siradj, MA. dalam ceramah ilmiahnya di STAIN Malang baru-baru ini (29/7/2000). Ketika ia berkunjung ke belahan dunia muslim lain, bangsa Indonesia di mata negarạ Iran misalnya, dianggapnya sebagai bangsa kanibal. Boleh jadi, selain Iran juga tidak jauh berbeda kesannya terhadap In- persoalan yang ingin penulis kupas dalam makalah ini adalah: apakah ada fungsi laten agama yang dapat memicu tindakan anarkisme kolektif? Apakah ada sesuatu yang clapat menggerakkkan orang sehingga ia melakukan kekerasan kolektif?. Bukankah mayoritas masyarakat Inclonesia adalah pemeluk agamaagama yang semuanya cinta damai? Dari pertanyaan-pertanyaan mendasar inilah, tulisan ini mengalir. 


\section{Fungsi Manifes dan fungsi Laten Agama}

Pada dasarnya, semua agama mengajarkan kepada pemeluknya untuk hidup dalam kedamaian. Bahkan agama muncul, baik secara teologis maupun sosiologis adalah guna menyantuni clan menyelamatkan anak manusia; menunjukkan jalan-jalan kedamaian dan keselamatan, menghilangkan ketidakpastian dan mendatangkan ketenteraman, mengajarkan kasih sayang diantara sesama manusia, makhluk lain dan lingkungan hidupnya, menyucikan diri dari perbuatan-perbuatan buruk, tercela atau merusak clan sebagainya (Sayyid Qutb dalam Azyumardi Azra, 1996: 182).

Melalui kacamata sosiologis, ditemukan bahwa secara umum agama hadir baik secalra individual maupun sosial memiliki dua fungsi. Pertaina, Thomas F. O'dea menyebut fungsi transendensi. Yakni sesuatu yang membuat pengalaman sehari-hari menjadi transenclen; kedua, agama bersifat profetis, yaitu agama menjacli pembimbing manusia dalam menjalani kehidupannya. Sèmentalra dalam pandangan Durkheim, fungsi sosial agama adalah mendukung dan melestarikan masyarakat yang sudah ada, baik terhadap kesatuan clan solidaritas sosial (Suprayogo dalam M. Yunus, 2000: 46). Lebih rinci D. Hendro Puspito, O.C. menyebutkan bahwa ada lima fungsi agama bagi manusia dan masyarakatnya, yakni: fungsi edukatif, fungsi penyelamatan, fungsi kontrol sosial, fungsi memupuk persaudaraan, clan fungsi transformatif (D. Hendropustpito, O.C., 1994: 38-56).

Bila kita perhatikan, agama sebagai suatu institusi sosial memiliki fungsi-fungsi positip sebagimana disebutkan di muka. Fungsi-fungsi positip itulah yang oleh Robert K. Merton disebut sebagai fungsi manifes, yakni fungsi yang diharapkan (intended). Sedangkan fungsi laten adalah sebaliknya, yaitu fungsi yang tidak diharapkan (George Ritzer, terj. Alimandan,
1992: 27). Dalam sejumlah masyarakat, fungsi manifes agama meliputi pengendalian negara secara aktual, seperti di Iran, di mana Sbab digantikan oleh theocracy yang dikendalikan oleh para ayatullab Muslim (Paul B. Hortun \& Chester L. Hunt, terj. Aminuddin Ram clan Titi Sobari, 1996: 310).

Fungsi yang tidak diharapkan atau disfungsi terlihat dari adanya pertentangan yang membahayakan keutuhan masyalrakat tidak jarang bersumber pada faktor agama. Konflik antara kaum Katolik dan Protestan di Irlandia Utara, antara kaum Sikh dan kaum Hindu di Negara bagian Punjab, antara kaum Muslim dan kaum Hindu di Ayodhya, antaral orang Palestina yang beragama Islam dan orang Israel yang beragama Yahudi, antalra kaum Kristen dan kaum Muslim di Nagorno-Karabach dan antara kaum Syiah dan kaum Sunni di Irak menunjukkan bahwa adanya agama berlainan atau aliran berbeda dalam agama yang sama dalam satu masyarakat dapat membahayakan keutuhan masyarakat tersebut (Kamanto Sunarto, 1993: 166-167).

Bagi masyarakat Indonesia yang sangat plural, perbedaan antara suku, etnis, budaya, bahasa, antar golongan, clan agama, menyebabkan penghayatan dan pengalaman keagamaan bangsa Indonesia unik dibandingkan dengan bangsa-bangsa lain. Fenomena semacam ini, di satu sisi merupakan modal dasar yang dapat memperkaya dinamikal keagamalan yang positip, namun di pilhak lain dapat menjadi hambatan dan mengancam kelangsungan kita dalam beragama sekaligus berbangsa... (Said Agiel Siradj, 2000: 9). Falktorfaktor inilah yang acapkali menjadi pemicu kekerasan kolektif berbau SARA (Suku, Agama, Ras, dan Antalr Golongan).

\section{Agama dan Akar Kekerasan Kolektif}

Kekerasan yang terus beruntun terjadi di 
tengah masyarakat kịta sejak bergulirnya reformasi, benar-benar membuat manusia yang berakal sehat dan berhati nurani tersentak kaget. Para pecinta damai seakan tak percaya, bahwa mayoritas masyarakat pemeluk agama yang dulu tampak tenang, ternyata menyimpan virus sosial yang dahsyat.

Situbondo, Tasikmalaya, Sanggau-Ledo, Rengasclengklok, Timtim, Jakarta, Solo, Karawang, Medan, Ambon, Sambas, dan lainlain adalah kota yang pernah membara (dalam arti clenotatif) karena agresivitas massa. Mengamuknya massa telah menimbulkan korban materiil yang tak terhingga banyaknyal. Dan yang terpenting, kerusuhan demi kerusuhan tersebut mengakibatkan kerugian moril yang substansial bagi upaya menegakkan persatuan clan kesaltuan bangsa (Muhammad Sofyan, 1999: 42-43).

Banyak para analisis yang dikemukakan oleh paral cendekiawan untuk mencari akar kekerasan kolektif tersebut. Bagi para agamawan dan pemerhati sosial keagamain, pacla

Nurcholish Madjid misalnya (Andito, ed., 1998: 155) memandang bahwa meninggalkankemutlakan

(absolutisme) adalah jalan menuju perdamaian. Lebih lanjut Armahedi Mahzar (Andito, ed., 1998:15) melihat adanya lima penyakit yang biasanya menghinggapi aktivis keagamaan, yaitu: absolutisme (kesombongan intelektual), eksklusivisme (kesombongan sosial), faratisme (kesombongan emosional), ekstremisme (berlebih-lebihan dalam bersikap) dan agresivisme (berlebihlebihan dalam tindakan fisik). umumnya berpendapat bahwa kekerasan kolektif muncul karena adanya kedangkalan pemahaman terhadap agamanya, sehingga melahirkan truth claim yang tidak fair. Nurcholish Macljicl misalnya (Andito, ed., 1998: 155) memandang bahwa meninggalkain kemutlakan (absolutisme) adalah jalan menuju perdamaian. Lebịh lanjut Armahedi Mahzar (Andito, ed., 1998: 15) melihat adanyal lima penyakit yang biasanya menghinggapi aktivis keagamaan, yaitu: absolutisme (kesombongan intelektual), eksklusivisme (kesombongan

\section{(Anciro, ed, 1999: 387). Kalau (likemuka} (Anclito, ed., 1999: 387). Kalau dikemukan dalam bahasa populer, pandangan Romo Mangun ini iclentik dengan jargon John Naisbit: Spirituality Yes, Organized Religion No. Pun sama pula dengan jargon Nurcholish Madjid beberapa tahun yang lalu sebelum era Reformasi bergulir: Islam Yes, Partai Islam, No.

Dalam bagian lain, Romo Mangun mensinyalir adanya keterkaitan antara kekerasan kolektif dengan istilah "amuk" massa. Kata "amuk" orisinil kosa kata masyarakalt Jawal Nusantara. Menurutnya, kata ini mengacu 
kepadal suatu bentuk amarah naik pitam, emosional, irrasional, dan sangat aneh. Seolaholah matal orang butal karrenanyal. Orang-orang luar negeri bisa malrah dan naik pitam, tetapi ticlak clisebutkan mengamuk (making amok). Orang Rwanda bisal saling bunuh, tetapi sepertinya acla kesadlaran icleologis tertentu untuk membunuh hanya karena perbedaan suku bangsa. Tetapi amuk khas Nusantalra cukup spesifik. Masyalrakat kita memiliki karakter ticlak muclah clikenclalikan (uncontrollable), tetapi mudah menyesal. Muclah melepas kontrol, tetapi mudah pula mendapatkan kontrol itu kembali untuk kemuclian menyesali segala akibat clari amuk (Muhammad Sofyan, 1999: 43-44).

Tesis Romo Mangun tersebut kiranyal cocok untuk menggambarkan situasi clan kondisi amuk massa salah saltu pendukung partai yaing merusak Kantor PEMDA Balli. Mereka juga membakar kenclaralan-kendlarain yang acla di situ, dan merobohkan pepohonan di clepan rumah-

Masyarakat kita memiliki karakter tidak mudah dikendalikan (uncontrollable), tetapi mudah menyesal. Mudah melepas kontrol, tetapi mudah pula mendapatkan kontrol itu kembali untuk kemudian menyesali segala akibat dari amuk rumalh penducluk di sekitar

jalanan kotal Bali. Peristiwa itu terjacli sesaat setelah pemimpin merekal gagal menempati posisi top leader cli negeri ini clalam Siclang Umum sekitar 1 tahun yang lalu. Dilihat dari sisi ini, karakter seperti tergambarkan cli. attas mendapat celah masuk untuk melampiaskan perilaku anarkisme massal. Setelah melakukan, clengan cepat pula mereka menyesali akibat perilakunyal.

Secara sosiologis, dapat dijelaskan bahwal perilaku anarkisme kolektif di muka ticlak bisal clilepaskan clari aclanya proses transisi multiclimensional. Masá transisi seiring dengan perubahan sosial yang sangat mendasar dan menyeluruh menyentuh hampir semua aspek kehiclupan cli negeri ini, membawa konsekwensi yang sangat besar bagi masyalakat.

Bila dilihat dari dimensi domestik, terdapat masa transisi dari masal yang sebelumnya tertutup menjadi serba terbuka. Orang ticlak sekedar bebas mengutarakan aspirasinya, lebih clari itu juga bebas menyattakan iclentitasnyal, baik iclentitas politik, maupun identitas primordialnya. Akibatnya, benturan antar iclentitas-pun sangat rentan terjadli. Ketika benturan itu ticlak terkontrol, pecalhah amuk massa. Salsarannya ialah atributatribut iclentitas lawan (Muhammad Sofyan, 1999: 53). Atribut-atribut identitas lawan itu bisa berupa identitas agamal seperti tempat ibaclah: masjicl, pura, klenteng, gereja, dan semacamnya. Bisa jacli atribut iclentitas itu berupal sentrasentra ekonomi etnis lain seperti toko-toko "pecinan" yang dijaclikan salsaran amuk massa. Tak terkecuali atribut iclentitas partai seperti kantor partai, benclera partai, bahkan pemimpin partai yang clijaclikan sasaran pelampiasan amuk massá.

Dalam kondisi seperti itu, terjaclilah disorganịsasi yang bisa memperparalh krisis. Pacla keadlaan clemikian, clijumpai suatu anomie yalitu suatu keadlaan di manal tak ada pegangan terhaclap apa yang baik clan apa yang buruk, sehingga angota-anggotanya ticlak mampu mengatur tinclakan-tindakannya, oleh karenal batas-battas tidlak adla (Soejono Soekanto, 1997: 375). Keadaan anomie inilah yang memungkinkan peristiwa tinclak kekerasan 
massa itu mudah terjadi. Dan apalagi unsur sentimen agama masuk di dalamnya, maka dalam situasi seperti ini batas antara agama dengan kekerasan sangatlah tipis.

Sementara bila clibaca clari perspektif global, masyarakat negeri ini sedang berada di era transisi clari kultur agraris menuju sistem ekonomi global. Transisi ini, mengalami proses yang paradoksal. Masyarakat kita "gagap" melihat perubahan-perubahan global yang sangat cepat itu. Ketika perekonomian seclang menuju satu titik universal (pasar bebas), justru adla indikasi menguat gejala tribalisme (kesukuan). Tentu saja, paradoks itu melambangkan sebuah konflik. Meminjam istilah Samuel Huntington, ada semacam benturan peradaban (Muhammad Sofyan, 1999: 53).

Pada prinsipnya, berbagai perbedaan bukanlah akar terjadinya tindak kekerasan. Tetapi manusialah yang acapkali salah dalam memaknai perbedaan itu. Sebab perbedaan merupakan order of natur atau sumnatullab (hukum alam) dalam bahasa Islam. Perbedaan adalah sesuatu yang alami. Tidak bisa kita bayangkan bagaimana jadinya, jika bumi dan langit beserta isinya ini semuanya sama. Tentu tidak ada dinamika, tidak ada ker jasama, bahkan tidak ada persaingan (dalam arti positip). Hidup ini pasti sangat menjenuhkan.

\section{Kontribusi Agama Bagi Perdamaian}

Pacla prinsipnya, berbagai perbedaan bukanlah akar terjadinya tinclak kekerasan. Tetapi manusialah yang acapkali salah clalam memaknai perbedaan itu. Sebab perbedaan merupakan order of natur atau sunnatullab (hukum alam) dalam bahasa Islam. Perbedaan adlalah sesuatu yang alami. Tidak bisa kital bayangkan bagaimana jadlinya, jika bumi dan langit beserta isinya ini semuanyal sama. Tentu ticlak adla clinamiką, tidak adla kerjasama, bahkan ticlak adla persalingan (dalam arti positip). Hidup ini pasti sangat menjenuhkan.

Oleh karena itu, persoalannya terletak clari bagaimana cara pandang kita terhadap adanya berbagai perbedaan itu. Islam misalnya, memandang perbedaan sebagai rahmat bagi sekalian alam (rabmatan lil alamin). Konsekuensinya, ajaran Islam ticlak pernah dan tidak akan pernah membolehkan pemaksaan dalam beragama. Islam memandang manusia Sama-sama sebagai mahluk Tuhan. Oleh karenanyal, Islam sangat menjunjung tinggi nilainilai kemanusialan seperti: persamaan (almusawab) kasih sayang (al-rabman-alrakbim), keadlilan (al-adl), dan sebagainya. Lewat nilainilai universal inilah mestinya peradaban clunia kita bangun. Bukan sebaliknya, clunia ini diruntuhkan karena kita saling berbeda. Islam clalam al-Quran (Q.S. Al-Maiclah: 48) mengajarkan: "berlombalobalah kalian semua clalam hal kebajikan" (fastabiquil kbairat). Perintah ini sangat relevan karena kita hiclup clalam perbedaan dan masyarakat yang plural.

Karena itu adlanya pluralitas bukanlah bencana, dan banyaknya agama itu merupakan kehendak Tuhan. Sebagaimana firmannya : ". . kalau tidak karena perlindungan Allab kepada manusia antara sebagaian mereka dengan sebagian yang lain, niscaya sudab diruntubkan biara-biara, gerejagereja, sinagog-sinagog, dan masjid-masjid, yang di dalamnya banyak disebut nama Allab ...".

Tetapi kenapa serentetan peristiwa menyedihkan itu bisa terjadi?' Dr. Alwi Syihab pernah berkata, bahwa tak ada satupun agama di clunia ini menganjurkan umatnya menghancurkan umat dan fasilitas ibadah agama lain. Apala gi, katanya, jika mereka mengklaim tinclakan anarkis itu dilakukan atas clasar perintah agama. Kalaupun itu terjadi juga, 
sebabnyal tidak lain karena penyimpangan umat beragama itu sendiri (Tekad, 14 Pebruari 1999 dalant Mohammad Sofyan, 1999: 84-85). Karrena itulah, umat beragama perlu belajar mengakui clan menerima berbagai perbedalan clalam hal beragama. Apalagi agamalagama yang acla di Indonesia, sama-sama menyebut nama Tuhan walau dengan bahasal yang berbeda-beda, dan sama-sama memperjuangkan perdamaian dan kassih salyang.

Namun demikian tidaklah cukup hanyal clengan mengakui adanya perbeclaan (baca: pluralisme) dalam banyak hal. Tetapi semestinyal sekaligus kita terlibat dalam perbedaan itu. Artinyal, walaupun kita tahu ada perbedalan, dan mengakui aclanya perbeclaan itu, --bila kita ticlak berusaha melibatkan diri dalam perbedalan tersebut-- tentu tidak akan banyak membantu terciptanya perdamaian universal. Sebagai misal, di Taman Mini Indonesia Indah (TMII) ada contoh menarik. Di sana berbagai simbol agama dan kebudayalan ada di dalamnya. Ada Masjicl, Pura, Gereja, Klenteng, dst. Demikian pula ada bangunan mini rumah adat Jawa, Minangkabalu, Timor-Timur dan sebagainya. Kemajemukan ini tidak akan membawa clampak positip, jika masing-masing penghuninyal hanya sibuk clengan dirinya sendiri. Mereka tidak mau terlibat dengan suka-cluka saludaranyal yang lain. Tidak ada interaksi clan komunikasi dengan pilak lain, mereka hanya mau berurusan dengan dirinya sendiri dan dengan siapa yang dianggap sama dengan dirinya. Walaupun tetangganyal lapar mau mati, bila mereka itu di luar agama, etnis, atau rasnya, clia ticlak mau peduli.

Contoh konkrit keterlibatan Nabi Muhammad Saw. dalam pluralitas itu aclalah ketika beliau membangun kota Madlinalh. Setelah beliau bersama para sahabat Muhajirin dan Ansar sukses membangun masjid pertama kali di Madinah, beliau menyatukan berbagai suku clan agama yang ada dan hidup di claerah itu. Sebalb masyarakat/negara Maclinalh tidak akan berdiri kokoh, jika tidak di dukung oleh seluruh komponen masyarakat yang adla. Karena itulah - beliau mempelopori penandatangan naskah kerjasama perdamaian dengan suku-suku yang ada di sana. Darri sini lahirlah apa yang populer dikenal dengan nama Piagam Madinah. Tercatat dalam buku Masyarakat Madani: Tinjauan Historis Kebidupan Zaman Nabi (Akram Dhiyauddin Umarri, terj. Mun'im A. Sirry, 1999: 37) teks clokumen perjanjian antala kaum Muslim clengan seluruh lapisan masyarakat Madlinah (Muhajirin, Ansar, Yahudi Bani Auf, Yahudi Banun-Naijjar, Yahudi Banul-Harits, Yahudi Bani Salidah, Yahudi Bani Jusyam, Yahudi Bani alAus, Yahudi Bani Tsálabah, dan lain-lain) yang berisi 47 palsal. Intinyal adalah pengakuan bahwa mereka aclalah satu komunitas (ummab) yang wajib menjaga keamanan dan menciptakan kesejahteraan bersama tanpa saling merasa terganggu.

Darri sinilah ada kata kunci yang bisa kita jadikan pegangan, yaitu: kemajemukan, perbedaan, clinamika, keterlibatan, interaksi, komunikasi, dan jalan-jalan alternatif. Bangsa Indonesia adalah bangsa yạng majemık, katrena itu wajar jika muncul adanya perbedaanperbedaan (SARA). Justru dengan adanya perbedaan inilah akan terjadi dinamika. Manusia sebagai makhluk sosial, tentu memerlukan bantuan pilak lain, karrena dirinya sendiri tidak akan mungkin clapat memenuhi segala kebutuhan hidupnya tanpa uluran pihak lain. Karena itulah manusia yang hiclup clalam satu bangsa, ticlak bisa menutup diri. Karena sesungguhnya bangsal yang menutup diri tidak akan cepat maju, misalnya Korea Utara yang clulunyal eksklusif itu.

Atas clasar itulah, manusia perlu terlibat clalam kemajemukan, berinteraksi dengan sesamanya. Dan apabila dalam berinteraksi 
menemui keganjilan-keganjilan, perlu cliselesaikan clengan jalan komunikasi (dialog) tanpa kekerasan. Disinilah letak betapa sesungguhnya ticlak ada kesulitan yang ticlak bisal kita pecalnkan, asal kan mau berkomunikasi. Jallan-jalan al ternatif masih banyak yang bisa kita lewati untuk menyelesaikan berbagai persoalan kehidupan. Dan agama, menawarkannya kepadal kita untuk meciptakan perdamaian itu.

\section{DAFTAR PUSTAKA}

Akram Dhiyauddin Umari, Prof., Dr., Masyarakat Madani (Tinjanan Historis Kebidupan Nabi), terj. Mun'im A. Sirry, Gemal Insani Press, Jakalıta, 1999.

Andito, ed., Atas Nama Agama Wacana Dalam Dialog "Bebas" Konflik, Pustakal Hiclayah, Bandung, 1998.

Azyumardi Azra, Dr., Pergolakan Politik Islam: Dari Fundamentalisme, Modernisme Hingga post-Modemisme, Paramadina, Jakarta, 1996.
D. Hendropuspito, O.C., Drs., Sosiologi Agama, Kanisius, Jakarta, 1996.

George Ritzer, Sosiologi Ilmu Pengetabuan Berparadigma Ganda, Saduran Drs. Alimanclan, Rajajwali Pers, Jakalrta, 1992.

Kamanto Sunarto, Pengantar Sosiologi, Lembagal Penerbit Fakultas Ekonomi Universitas Inclonesia, Jakaluta, 1993.

Muhammad Sofyan, Agama dan Kekerasan Dalam Bingkai Reformasi, Medial Pressindo, Yogyakalutal, 1999.

M. Amin Abclullah, Dr., Studi Agama: Normativitas atau Historisitas?, Pustaka Pelajar, Yogyakarta, 1999.

Paul B. Horton clan Chester L. Hunt, Sosiologi, terj. Aminuddin Ram dan Titi Sobarri, edisi keenam, jilid 1, Erlangga, Jakartal, 1996.

Said Agiel Siradj; Dr., KH., ceramah ilmiahn clalam rangkal "Kuliah Tamu" di STAIN Malang, Sábtu, 29 Juli 2000.

Soejono Soekanto, Prof. Dr., S.H., M.A., Sosilogi Suatu Pengantar, PT. RajjaGrafindo Persada, Jakartal, Cet. Ke-24, 1997. 